


\title{
The Inevitability of the USSR Collapse and the Emergence of New Russia in the Mass Media
}

\author{
DOI: https://doi.org/10.46398/cuestpol.3969.20
}

Lusine Ovakimovna Muradian *

Abbas Mohammadovich Dzhuma **

Ntentie Mari Nzhipuakuyu ***

Khussein Madzhid Kasem Salekh ${ }^{* * *}$

\begin{abstract}
From a documentary perspective the article addresses issues such as the collapse of the Soviet Union, separatism in the USSR and the existence of similar destructive processes in modern Russia. Special attention is paid to the role of the media in the collapse of the USSR. The goal was to find out whether the collapse of the Soviet Union and the rise of New Russia were inevitable. Consequently, the additional objectives of the article are to identify the main reasons for the collapse of the USSR, to draw an analogy with the situation in modern Russia, to analyze propaganda techniques by examining the Moscow News newspaper, and to study and generalize the main problems of inter-ethnic dialogue in the Soviet and post-Soviet space. The relevance of the topic is justified by the lack of a unified view in the community of experts on the causes and consequences of the collapse of the USSR, as well as by the lack of a unified assessment of the period of Perestroika and the inevitability of the transition from socialism to capitalism in Russia. It is concluded that in the geopolitical phenomenon of the collapse of the USSR occupies a special role the national and international media dimension.
\end{abstract}

Keywords: Russia; USA; mass media; autonomy; federalism.

\footnotetext{
* People's Friendship Russian University of Russia (RUDN University), Moscow, Russia. ORCID ID: https://orcid.org/oooo-0oo2-1367-2223. Email: lurdes_lesli@mail.ru

** People's Friendship Russian University of Russia (RUDN University), Moscow, Russia. ORCID ID: https://orcid.org/oooo-ooo1-9891-9434. Email: abbasrudn@mail.ru

*** People's Friendship Russian University of Russia (RUDN University), Moscow, Russia. ORCID ID: https://orcid.org/o0oo-0003-0789-3780. Email: njimarie2002@mail.ru

****Academy of Labour and Social Relations, Moscow, Russia. ORCID ID: https://orcid.org/oooo-ooo22978-7519. Email: majedqasem@mail.ru
} 
Lusine Ovakimovna Muradian, Abbas Mohammadovich Dzhuma, Ntentie Mari Nzhipuakuyu y Khussein Madzhid Kasem Salekh

336

The Inevitability of the USSR Collapse and the Emergence of New Russia in the Mass Media

\section{La inevitabilidad del colapso de la URSS y el surgimiento de una nueva Rusia en los medios de comunicación}

\section{Resumen}

Desde una perspectiva documental el artículo aborda temas como el colapso de la Unión Soviética, el separatismo en la URSS y la existencia de procesos destructivos similares en la Rusia moderna. Se presta especial atención al papel de los medios de comunicación en el colapso de la URSS. El objetivo fue averiguar si el colapso de la Unión Soviética y el surgimiento de la Nueva Rusia fueron inevitables. En consecuencia, los objetivos adicionales del artículo son identificar las principales razones del colapso de la URSS, establecer una analogía con la situación en la Rusia moderna, analizar las técnicas de propaganda examinando el periódico Moscow News y estudiar y generalizar los principales problemas del diálogo interétnico en el espacio soviético y postsoviético. La relevancia del tema se justifica por la falta de un punto de vista unificado en la comunidad de expertos sobre las causas y consecuencias del colapso de la URSS, así como por la falta de una evaluación unificada del período de la Perestroika y la inevitabilidad de la transición desde del socialismo al capitalismo en Rusia. Se concluye que en el fenómeno geopolítico del colapso de la URRS ocupa un papel especial la dimensión mediática nacional e internacional.

Palabras clave: Rusia; EE. UU; medios de comunicación en masa; autonomía; federalismo.

\section{Introduction}

After 70 years of the fraternity of the Soviet peoples, as a result of the desire of some ethnic, sub-ethnic and regional groups for sovereignty or autonomy, the Russian Federation appeared in the 1990s. After the collapse of the USSR, separatist sentiments emerged in Russia. The most striking and aggressive separatist movement was in the Republic of Ichkeria (Chechnya) with the subsequent heavy fighting against federal troops. Separatism began to gradually emerge in Dagestan, Ingushetia, Tuva, Tatarstan, Bashkortostan, Yakutia, Buryatia and even in some regions inhabited mainly by Russians. Since the 2000s, separatism in Russia has been gradually declining, although its potential remains great. The collapse of the Russian Federation according to the scenario of the collapse of the USSR was a threat for a long time, and only the right policy of Moscow in the 2000 s made it possible to stabilize the situation. Nevertheless, the threat of separatism in Russia remains relevant. Formally, the relevance of the threat 
of separatism is confirmed by the existence of Article 280.1 of the Criminal Code of the Russian Federation, which provides deprivation of liberty for up to three years for public appeals to take actions aimed at violating the territorial integrity of the Russian Federation. For similar actions using the mass media and the Internet, the term of imprisonment is increased to 5 years. In the summer of 2014, these standards were tightened.

Despite this, today, the issue of the state structure of Russia remains one of the most controversial among scholars and politicians. Some of them insist on the status quo, while others are convinced that a federation, especially an "ethnic" one, is destructive for Russia. There are ongoing disputes in the expert community about the inevitability, as well as the consequences of the collapse of the USSR. To figure out who is right and to find the truth, it is necessary to analyse the key reasons for the collapse of the Soviet Union and to deepen the understanding of political and ideological contradictions in Russia, which remain relevant today.

\section{Materials and methods}

Defending the ideas of the unitarization of the country, one can appeal to the ideas of representatives of the Russian school such as F.F. Kokoshkin, I.A. Ilyin and others. At the very beginning of the formation of the Russian Soviet Federative Socialist Republic in the 1920s, after it, during the adoption of the Constitution of the USSR in 1936 and the Constitution of the Russian Federation in 1993 and even today, the issue of the need to transform the Russian Federation into the Russian Republic is insistently raised. According to the authors of the initiative, it would equalize the rights of the Russians with the peoples who have their national statehood in the Russian Federation. There are still many supporters of "gubernization" (division into provinces) and, on the contrary, the federalization of Russia (Konyukhova, 2006).

There is a certain concept, hence, a part of civil society, behind each of the positions. These concepts can either unite or divide society; therefore, a constant search for agreement and an exit to the legislatively enshrined state doctrine of national and federal politics are necessary. The 1996 concept of the state nationality policy of the Russian Federation is outdated; it no longer provides answers to the challenges of modern time (Konyukhova, 2006). Therefore, it is extremely important at a new stage in the country's development to identify and scientifically substantiate the priorities in nation-building, ethnocultural policy and interethnic relations, which would, at the same time, preserve and transfer the accumulated experience (Konyukhova, 2006). There was such an experience in Imperial Russia and the Soviet Union. Yet, the connection between the times was interrupted for 
ideological reasons: first through the fault of the Communist Party of the Soviet Union and the Soviet regime, then through the fault of democratic Russia, not without external influence.

In this regard, the key factor is an objective interpretation of conceptual approaches to solving the examined problem in a historical retrospective (Stalin, 1949).

In Russian history, state integrity was destroyed twice, and the scenarios were similar. First, in 1917-1918, when the world revolution was broken out for the sake of victory over capitalism. Then, in the 1990s, when the national separatism was used under the slogan of self-determination of nations for the sake of an open society and victory over communism. The lessons of the past can help in strengthening the unity of the Russian peoples, as well as in choosing perfect forms and methods of the state structure of the country (Stalin, 1949).

\section{Results}

The collapse of the Soviet Union and the following threat of the collapse of the Russian Federation are mainly caused by subjective circumstances. Conceptually, the disintegration mechanism was programmed by the VII (April) All-Russian Conference of the Russian Social Democratic Workers' Party of 1917, which, following V.I. Lenin's suggestion, adopted resolution on the demand for the right to free secession and the formation of an independent state for all nations that are part of the USSR, which contradicted the guidelines of the Second International on national selfdetermination and world practice (Konyukhova, 2006). This mechanism of disintegration was no longer theoretical; it was put into action on December 30, 1922, with the adoption of the Declaration and Treaty on the Creation of the USSR, when each republic was assigned the right of free secession from the USSR. This right was exercised by the union republics in 1991 (Abdulatipov and Mikhailova, 2010).

However, it is not entirely correct to argue that the collapse of the USSR occurred only because there was a legal possibility for collapse. Today, it is possible to consider in more detail the reasons for it. After such consideration, it becomes obvious that several factors played an important role in this process (Baglai, 2009).

Even during the existence of the USSR, the press reflected fears about the possible collapse. Historians identify the degradation of the management system, the economic crisis, the crisis of communist ideology and the rapid growth of democratic sentiments in Soviet society as the main prerequisites (Popov, 1990). Among the main reasons for the collapse of the Soviet 
system, experts consider the intraparty tensions, which were based on the personal ambitions of M.S. Gorbachev, the former General Secretary of the Communist Party of the Soviet Union (Chernyaev, 2011).

Since the late 1990s, theories of the collapse of the Soviet Union have begun to appear. In addition to internal reasons, external ones also began to be recognized. Namely, the United States and Western media's interference in these processes. Thus, Igor Panarin, political scientist, is confident that the victory of the USSR in the Second World War marked the beginning of the collapse of the Western colonial system and contributed to the integration of new subjects of geopolitics. The Soviet Union became a superpower, and the world order became bipolar, which resulted in the Cold War between the USA and the USSR (from 1946 until the collapse of the USSR in 1991) (Boltenkova, 2012). These factors caused an unprecedented anti-Soviet information campaign in the West. The project of globalization required justification and after the defeat of Hitler's Germany, the USSR became the main threat to the "open society" (Mikhailova, 2010).

Allen Welsh Dulles, Director of Central Intelligence, advocated the struggle against the Soviet regime. He formulated the key strategic goals of conducting information and ideological war against the Soviet Union, which are relevant up today.

It suggests that the version that includes all aspects is the closest to reality, since the problem of the collapse of the USSR appears to be a multifaceted and global process. Consequently, we can conclude that there were internal party tensions, as well as the impact of third forces: the information and psychological war waged by the United States (Mikhailova, 2002). According to V.A. Lisichkin, the Soviet and Russian economist, the main goal of the information confrontation was a large-scale impact on public opinion both in the Soviet Union and abroad. The key role belonged to the mass media. V.A. Lisichkin writes about three stages of the information and psychological war against the USSR: the introduction of citizens closely connected with the CIA to high positions under Gorbachev, the control of the key mass media and the destabilization of the economy (Mikhailova, 2002).

As for the methods of waging information war through the mass media, V.A. Lisichkin identifies the following techniques. Firstly, limiting the alternative point of view in the press. Secondly, the glut of the information space with topics that were atypical of the Soviet mass media: those related to the cult of money and consumption, the Western model of the development of society (including the family), as well as with unusual for Soviet people entertainment. Thirdly, the pursuit of a policy of historical revisionism in the mass media. Fourthly, total disinformation related to events taking place in both the USSR and abroad (Mikhailova, 2002). 
Lusine Ovakimovna Muradian, Abbas Mohammadovich Dzhuma, Ntentie Mari Nzhipuakuyu y Khussein Madzhid Kasem Salekh

Thus, Mikhail Gorbachev in his report in 1988 announced the need to restore historical justice concerning those who died as a result of mass repressions. It was the year when the print media published the largest number of materials on the topic of repression. The Soviet press was flooded with publications about the fault of the repressed Bolsheviks, as well as the memories of those who passed through the Main Directorate of Camps (GULAG) and their children. Articles about the tragic fate of the children of "enemies of the people" became extremely popular (Panarin, 2010).

The Perestroika period was unique, since, on the one hand, there was a request to discredit the Soviet communist system and, on the other hand, there was an opportunity to involve directly the victims of repression in this process, which at that time included many media workers. Thus, the role of the Moscow News newspaper ("MN") was especially remarkable in covering the topic of repression. It was believed that "MN" was the most popular newspaper and the most accurate in reflecting public sentiment. This statement is just as true as thy one that "MN" formed these sentiments, and it happened often with the help of crude propaganda techniques. Thus, in the 9 June 1991 issue of "MN", an article was published with the headline "President Yeltsin: For or Against? For! Why?". We are talking about an interview with Alexander Gelman, the People's Deputy of the USSR, where he urged Russians to vote for Yeltsin, calling him a man who sought the development of democracy and market relations, as well as the formation of a state of law (Lisichkin and Shelepin, 1999).

All these years, Yeltsin did not avoid but sought responsibility. Just think, what it means for the democrats, for their leader, to take full responsibility for the development of Russia, its cities and regions today, after the destructive decades of the domination of the totalitarian regime? Would not it be more profitable to remain the "invincible opposition" for a few more years? The economic recovery will not be rapid and triumphant. Adjusting interethnic relations will also require a lot of time and effort. What about the privatization processes, the fight against monopoly, the organization of the free market? How about attracting Western capital to help us? All these are problems that are difficult to solve, they can not only break one's career but also break one's head. Yet, we all, voters, will forget in six months that all these problems were not caused by the democrats, not by Yeltsin, and in six months we will be holding him accountable with all our impatience. Yeltsin is, of course, aware of all this. If he is nevertheless ready to take responsibility, then he does it not only because he is powerhungry. He believes in the power of his responsibility (Panarin, 2010: 153).

This is just one among hundreds and thousands of examples of systematic destructive work by the media during the period of the undermining of the Soviet system before the collapse of the Soviet Union. Similar mechanisms of destruction, although in a "narrowed" legal field, remain in the Russian Federation today (Panarin, 2010). 


\section{Discussion}

Based on the analysed facts, it can be argued that throughout the history of Russia, regardless of its state and political regimes, such factors as the ethnic composition, features of life and religious beliefs of the population of a particular region of the country have always been taken into account. In other words, the interconnection of ethnic and territorial factors has always been a constant attribute of state policy both in Imperial Russia and in the Soviet Union. It remains the same in modern Russia (Baglai, 2009). The conceptual difference of this relationship is determined only by the differences in the state structure. The new conclusion is that the conceptual thesis of the "right of peoples to self-determinate up to division and formation of an independent state" was not dictated by the situation in Russia, but was given to the general public to radicalize the situation (Abdulatipov and Mikhailova, 2010: 98). Mass media, both foreign and Soviet, played a significant role in this.

\section{Conclusion}

The Russian Federation has a complex ethnic composition. The share of Russians in the population is less than $50 \%$ in 13 out of 85 federal subjects of the Russian Federation. The regions with the highest share of titular ethnic groups include the North Caucasian republics and Tuva. The separatist movement in the Russian North Caucasus has a long and rich history, including the existing states and those that tried to become independent, of both individual peoples and ethnic groups, and several peoples in certain periods: pre-Russian, tsarist, the period of civil war and the collapse of the USSR (Lisichkin and Shelepin, 1999).

In 1990, the Supreme Council of the Tatar Autonomous Soviet Socialist Republic adopted the Declaration on State Sovereignty of the Republic of Tatarstan. The declaration, unlike some of the union republics and almost all other autonomous Russian (except for Checheno-Ingushetia) republics, did not indicate the location of the republic either in the RSFSR or in the USSR. It was declared that Tatarstan, as a sovereign state and a subject of international law, concludes treaties and alliances with Russia and other states. During the collapse of the USSR and later, Tatarstan adopted declarations and resolutions on the act of independence and entry into the CIS with the same wording. A referendum was held, and a constitution was adopted (Yeltsincenter, 1991).

In 2020, Tatarstan celebrates 30 years since the adoption of the declaration of state sovereignty. According to Rustam Minnikhanov, the president of the republic, the document defined "the modern development of Tatarstan" and helped to build trusting relations with Moscow. 
Lusine Ovakimovna Muradian, Abbas Mohammadovich Dzhuma, Ntentie Mari Nzhipuakuyu y Khussein Madzhid Kasem Salekh

The fact that there is a threat of political disintegration in modern Russia is indirectly evidenced by the fact that the events of 1989-1991 are to some extent similar to the events of 1917. The tsarist empire, like the USSR, collapsed due to the loss of public confidence. That is why the external intervention in these processes became possible. According to Pavel Milyukov, a Russian historian, revolutions become inevitable when the government evoke mockery and contempt instead of fear.

Thus, given these and other problems, we can conclude that the collapse of the USSR was an inevitable historical process provoked by several factors, the most important of which can be considered the decline of ideology and, as a consequence, Westernization, imposed mainly through the mass media. All this became possible and was aggravated by the strongest social, economic and political crisis, as a result of which the Communist Party lost its power monopoly.

\section{Bibliographic References}

ABDULATIPOV, Dzhamal Ramazanovich; MIKHAILOVA, Natalia Vyacheslavovna. 2010. Federalism as a democratic form of arrangement of territories and peoples of Russia. Etnosotsium. Moscow, Russia.

BAGLAI, Marat Viktorovich. 2009. Constitutional law of the Russian Federation. Norma. Moscow, Russia.

BOLTENKOVA, Lyubov Fedorovna. 2012. "Material based on the article by Vladimir Putin Russia: The National Question" In: National and federal relations questions. Vol. 1, No. 16, pp. 96-97.

CHERNYAEV, Anatoly S. 2011. "Soviet society: why the Soviet Union collapsed" In: Gorbachev's readings. Issue 9. Two coups and the collapse of the USSR. Gorbachev-Fond. Moscow, Russia.

KONYUKHOVA, Irina Anatolyevna. 2006. Modern Russian federalism and world experience: the results of the formation and development prospects. Gorodets. Moscow, Russia.

LISICHKIN, Vladimir Alexandrovich; SHELEPIN, Leonid Alexandrovich. 1999. The Third World (Information and psychological) War. Academy of Social Sciences. Moscow, Russia.

MIKHAILOVA, Natalia Vyacheslavovna. 2002. Russian federalism in the context of the world experience: dissertation ... candidate of political sciences: 23.00.02. Russian Academy of Public Administration under the President of the Russian Federation. Moscow, Russia. 
MIKHAILOVA, Natalia Vyacheslavovna. 2010. "On the "fourth foundation of the federation” In: Free thought. Vol. 9, No. 1616, pp. 65-76.

PANARIN, Igor Nikolaevich. 2010. The First World Information War. Collapse of the USSR. Piter. St. Petersburg, Russia.

POPOV, N. 1990. "The crisis of trust is the crisis of power" In: Ogonek. Vol. 7, pp. 2-4.

STALIN, Joseph Vissarionovich. 1949. The National Question and Leninism. Vol. 11. Gosudarstvennoye izdatel'stvo politicheskoy literatury. Moscow, Russia.

YELTSINCENTER. 1991. Available online. In: http://www.yeltsincenter.ru/ digest/release/den-za-dnem-9-iyunya-1991-goda. Consultation date: $15 / 12 / 2020$. 
Vol. 39 N $^{\circ} 69$

Esta revista fue editada en formato digital y publicada en julio de 2021, por el Fondo Editorial Serbiluz, Universidad del Zulia. Maracaibo-Venezuela 